\title{
Late treatment of mandible fracture after third molar removal
}

\author{
Tratamento tardio de fratura mandibular após extração de terceiro molar \\ Tratamiento tardio de la fractura de mandíbula post exodoncia de tercer molar
}

Received: 01/12/2022 | Reviewed: 01/20/2022 | Accept: 01/22/2022 | Published: 01/24/2022

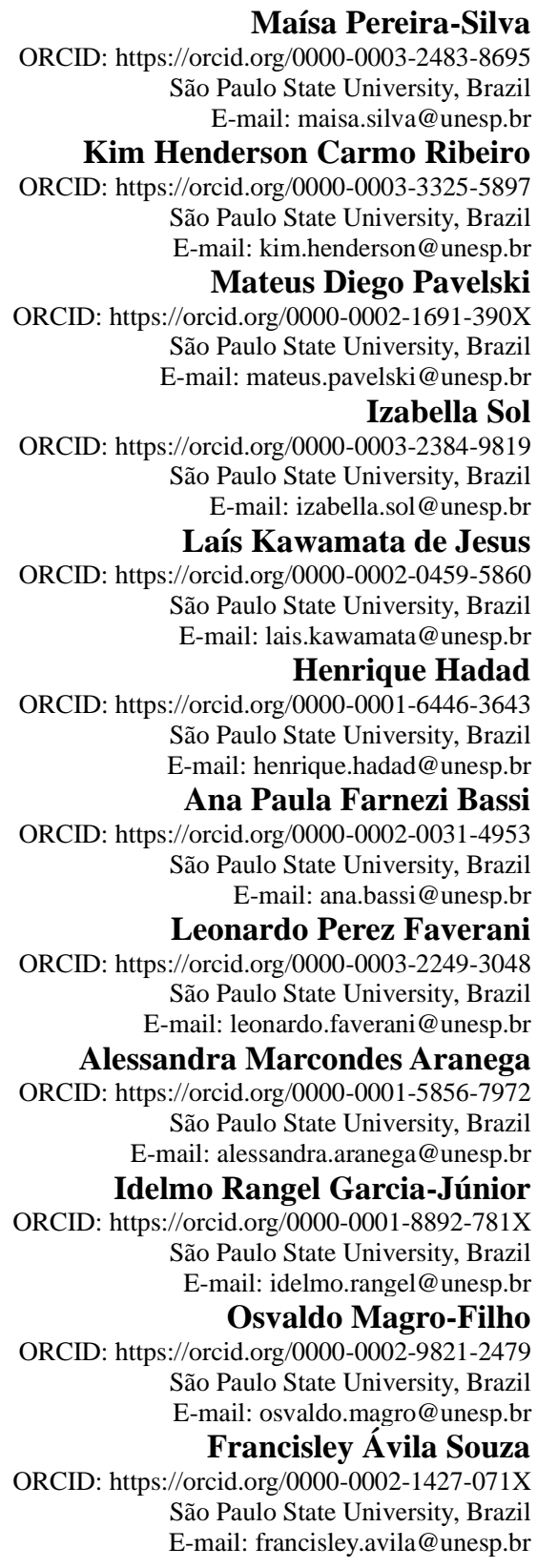

\begin{abstract}
Surgical management of impacted third molars is a treatment performed by dentists and its indicated for various conditions, among the indications has the prevention of mandibular fracture, but this is a factor that has been discussed and is controversial. Fractures caused by a third molar can occur, and on the other hand, the fractures after or during the management of impacted third molar are a possible complication. Surgical planning as the indication to the surgery has to be performed to avoid complications as the fracture. Thus this study aims to report a case about a mandible fracture after third molar extraction, presenting edema, pain, and restriction in mandible mobility in 01-day follow-up. A 27-year-old female was referred to the oral and maxillofacial surgery service of the Santa Casa Hospital of Araçatuba (Araçatuba, Brazil), reporting dental history of third molar removal, with immediately chief complaints.
\end{abstract}


In the assessment, the patient presented edema, pain, malocclusion, and restriction in mandible mobility, and the panoramic X-ray showed a mandible fracture with displacement. The patient underwent surgery under general anesthesia to open reduction with internal fixation (ORIF) through an intraoral approach. On the follow-up, the patient showed an improvement in mouth opening and mandibular mobility without pain or infection signs. The panoramic $\mathrm{X}$-Rays showed us the bone fracture healing.

Keywords: Third molar; Bone fracture; Pain; Malocclusion.

\section{Resumo}

O tratamento cirúrgico dos terceiros molares inclusos é um tratamento comumente realizado pelos dentistas e indicado em diversas condições. A prevenção de fratura mandibular está entre as indicações para a realização da exodontia, mas este é um fator que vem sendo discutido e é controverso. Fraturas causadas pela presença do terceiro molar podem ocorrer e, por outro lado, as fraturas após ou durante o procedimento cirúrgico do terceiro molar incluso são uma possível complicação. Portanto, o planejamento cirúrgico, assim como a indicação da cirurgia tem que ser realizado cuidadosamente para evitar complicações como a fratura. O objetivo deste estudo é relatar um caso de fratura de mandíbula após exodontia de terceiros molares, apresentando no acompanhamento edema, dor e restrição dos movimentos mandibulares. Paciente do gênero feminino, 27 anos, foi encaminhada ao serviço de Cirurgia e Traumatologia Buco-Maxilo-Facial da Santa Casa de Araçatuba (Araçatuba, Brasil), relatando ter sido submetida a exodontia de terceiro molar, e imediatamente apresentou queixas importantes. Na avaliação a paciente apresentou edema, dor, maloclusão e restrição nos movimentos mandibulares, e na radiografia apresentou fratura de mandíbula com deslocamento. Após o diagnóstico, a paciente foi submetida à cirurgia sob anestesia geral para redução aberta com fixação interna (ORIF) por acesso intra-oral. No acompanhamento a paciente apresentou melhora da abertura bucal e dos movimentos mandibulares sem sinais de dor ou infecção e as radiografias panorâmicas nos mostraram sinais de reparo da região da fratura óssea.

Palavras-chave: Terceiro molar; Fraturas ósseas; Dor; Má oclusão.

\section{Resumen}

El manejo quirúrgico de los terceros molares impactados es un tratamiento común que realizan los dentistas y está indicado para diversas afecciones, entre las indicaciones tiene la prevención de la fractura mandibular, pero este es un factor que ha sido discutido y es controvertido. Pueden ocurrir fracturas causadas por la presencia del tercer molar por otro lado, las fracturas después o durante el manejo del tercer molar impactado son una posible complicación. Por tanto, la planificación quirúrgica, como la indicación de la cirugía, debe realizarse para evitar complicaciones como la fractura. El objetivo de este estudio es reportar un caso sobre una fractura de mandíbula luego después de la extracción del tercer molar, presentando en el seguimiento de 01 día edema, dolor y restricción en la movilidad mandibular. Una mujer de 27 años fue remitida al servicio de cirugía oral y maxilofacial del Hospital Santa Casa de Araçatuba (Araçatuba, Brasil), informando que se sometió a la extracción del tercer molar, e inmediatamente presentó las quejas principales y mantuvo el edema, dolor, malloclusión y restricción de la movilidad mandibular. En radiografía presentó fractura de mandíbula con desplazamiento. Tras el diagnóstico, el paciente fue intervenido quirúrgicamente bajo anestesia general para reducción abierta con fijación interna (ORIF) mediante abordaje intraoral. En el seguimiento, la paciente presenta una mejora en su capacidad para abrir la boca y la movilidad mandibular sin signos de dolor o infección y la radiografía panorámica nos muestra una curación de la fractura ósea.

Palabras clave: Tercer molar; Fracturas ósseas; Dolor; Maloclusión.

\section{Introduction}

Surgical management of impacted third molars is a common treatment performed for general dentists and oral maxillofacial surgeons. The third molar management presents various indications as pericoronitis prevention or treatment, management of unexplained pain, prevention of caries, root resorption of adjacent teeth, orthodontic considerations, teeth under dental prosthesis, crowding of mandibular incisors, obstruction of orthodontic treatment, systemic health considerations, prevention of odontogenic cysts and tumors, economic considerations, periodontal disease and preparation for orthognathic surgery (Peñarrocha-Diago et al. 2021; Marciani, 2007).

Besides the cases cited before jaw fracture prevention is another factor to perform the extraction, but this is a controversial factor (Ventä, 2012; Seeley-Hacker et al. 2020). Mandible is considered the strongest bone commonly fractured because of its anatomic position (Miloro et al. 2008; Banks, 1991). The presence of the third molar in the mandible increased 2.18-fold for an angle fracture, on the cases of class IC, IIC, IIIB, or IIIC of Pell-Gregory scales increased 3.6-fold (Soós et al. 2020). 
Fractures caused by a third molar can occur, and on the other hand, the fractures after or during the management of impacted third molar are a possible complication. Therefore, the surgical management of the surgeon should plan the surgery for each case of third molar extraction because it requires accurate clinical examination and image evaluation to lessen the risk of fracture.

Planning surgery and the surgical techniques are the principal points observed in the third molar surgery. The extensive ostectomy (Pires et al. 2017) and the force (Liu et al. 2018) in extraction can cause the mandible fracture, such as the late fracture associated with mandible fragility after ostectomy (Pires et al. 2017). The aim is to report a case about a mandible fracture after third molar extraction, presenting in 01-day follow-up edema, pain, and restriction in mandible mobility.

\section{Methodology}

The present paper consists of a case report of a patient evaluated in Santa Casa Hospital of Araçatuba with a mandibular fracture in third molar removal conducted with surgical management presenting satisfactory results. This study applied the methodology described in Pereira (2018) and a Free and Clarified Term Consent.

\section{Case Report}

A 27-year-old female was referred to the oral and maxillofacial surgery service of the Santa Casa Hospital of Araçatuba (Araçatuba, Brazil), in April 2021, complaining of facial edema, pain and restriction of mandible mobility. The patient reported that was performed a surgery for tooth extraction and immediately the patient presented the chief complains. These were maintained in the follow-ups that were performed by patient's dentist, who did the surgery. Without improvement of complains, radiographic examination was performed in 30 days postoperative, and was observed the mandible fracture and the patient was referred to the hospital. At the hospital patient was assessment by the team and the chief complains was noted as restriction of mandible mobility, associated to a pain, malocclusion, bone crepitation during mandible manipulation and submandibular edema. In panoramic X-ray was noted the mandible fracture with displacement and was confirmed with CT (computed tomography) Scan. (Figure 1) 
Figure 1. A) CT Scans presenting the mandible fracture displacement. B) X-Ray performed in 30 days after third molar removal that was observed the fracture.
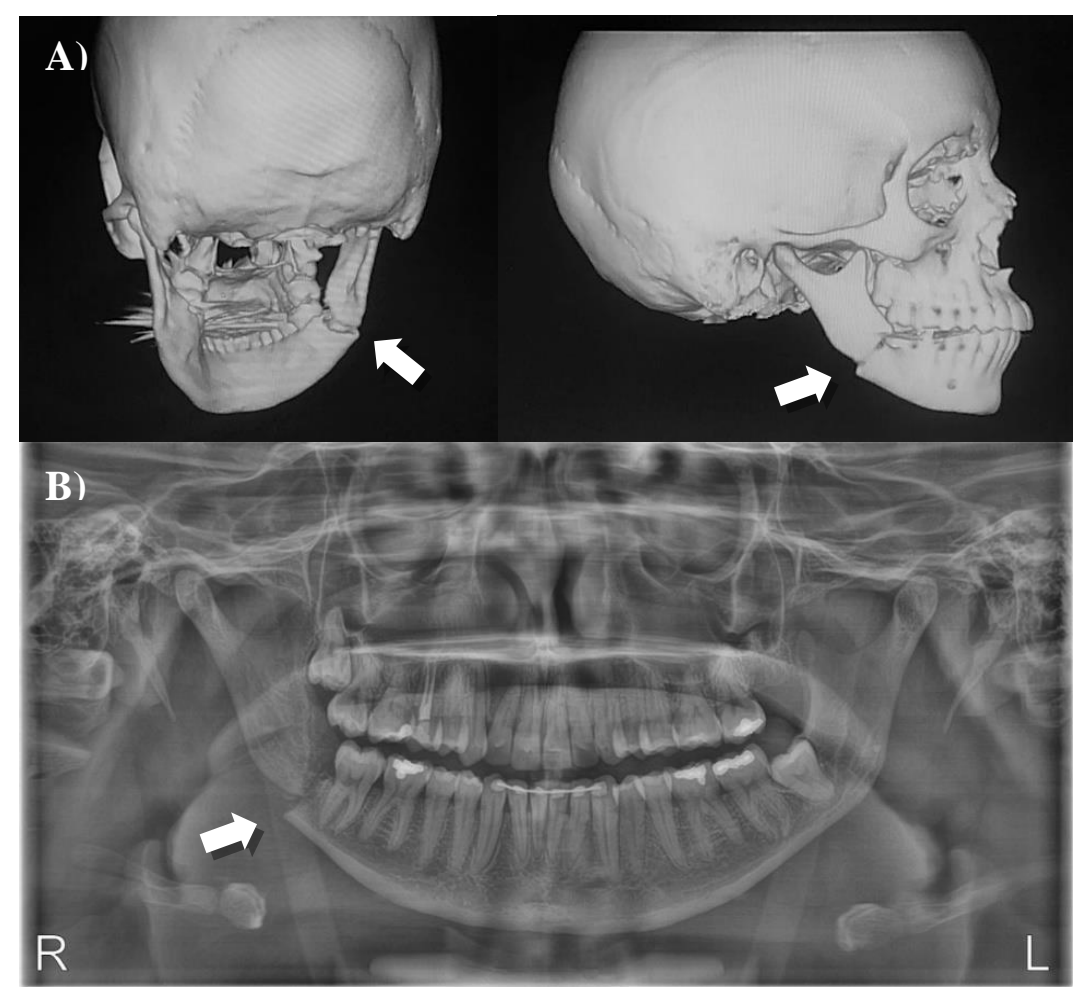

Source: Own authorship.

Under general anesthesia patient was submitted to a surgical management to open reduction with internal fixation (ORIF) through an intraoral approach were chosen as treatment. After anesthesia, the infiltration was performed to homeostasis. An incision following the anterior margin of mandibular ramus and extending to the retromolar to the vestibular region to expose the mandible fracture. After this the intermaxillary fixation (IMF) with screws was applied and then reduced and fixed the fracture with two 2.0-mm plates and screws. The mouth could be opened, and occlusion was checked. The wound was sutured using 4.0 Vicryl (Johnson \& Johnson-São Paulo/Brasil), and the IMF screw was removed. (Figure 2)

Figure 2. A) Intermaxillary fixation (IMF) screws was applied to maintain the occlusion. B) Intraoral approach and rigid fixation with two 2.0-mm plates and screws.

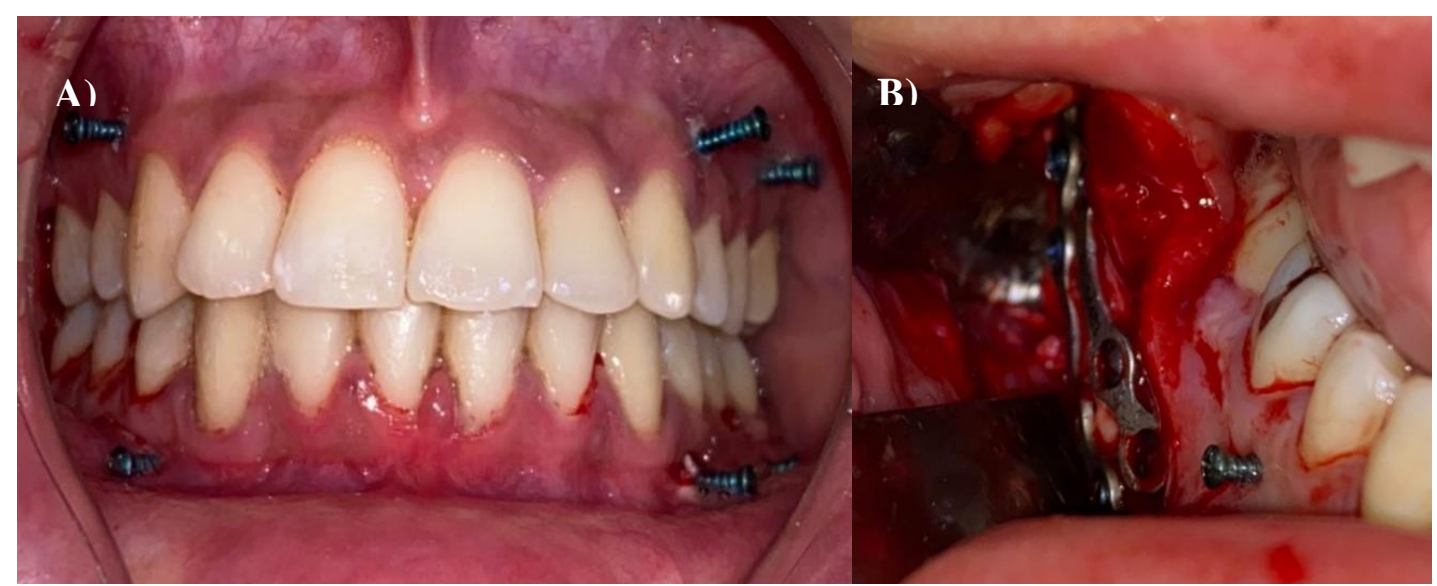

Source: Own authorship. 
A postoperative CT Scan was performed and showed an acceptable reduction of the fracture. On 75 days of followup, the patient improved her ability to open her mouth and mandibular mobility without pain or infection signs and the panoramic X-Rays shows us a healing of bone fracture. (Figure 3)

Figure 3. A) CT Scans presenting the acceptable reduction of the mandible fracture and plates positioning. B) Panoramic XRay performed in 75 days postoperative, presenting a healing of bone fracture.

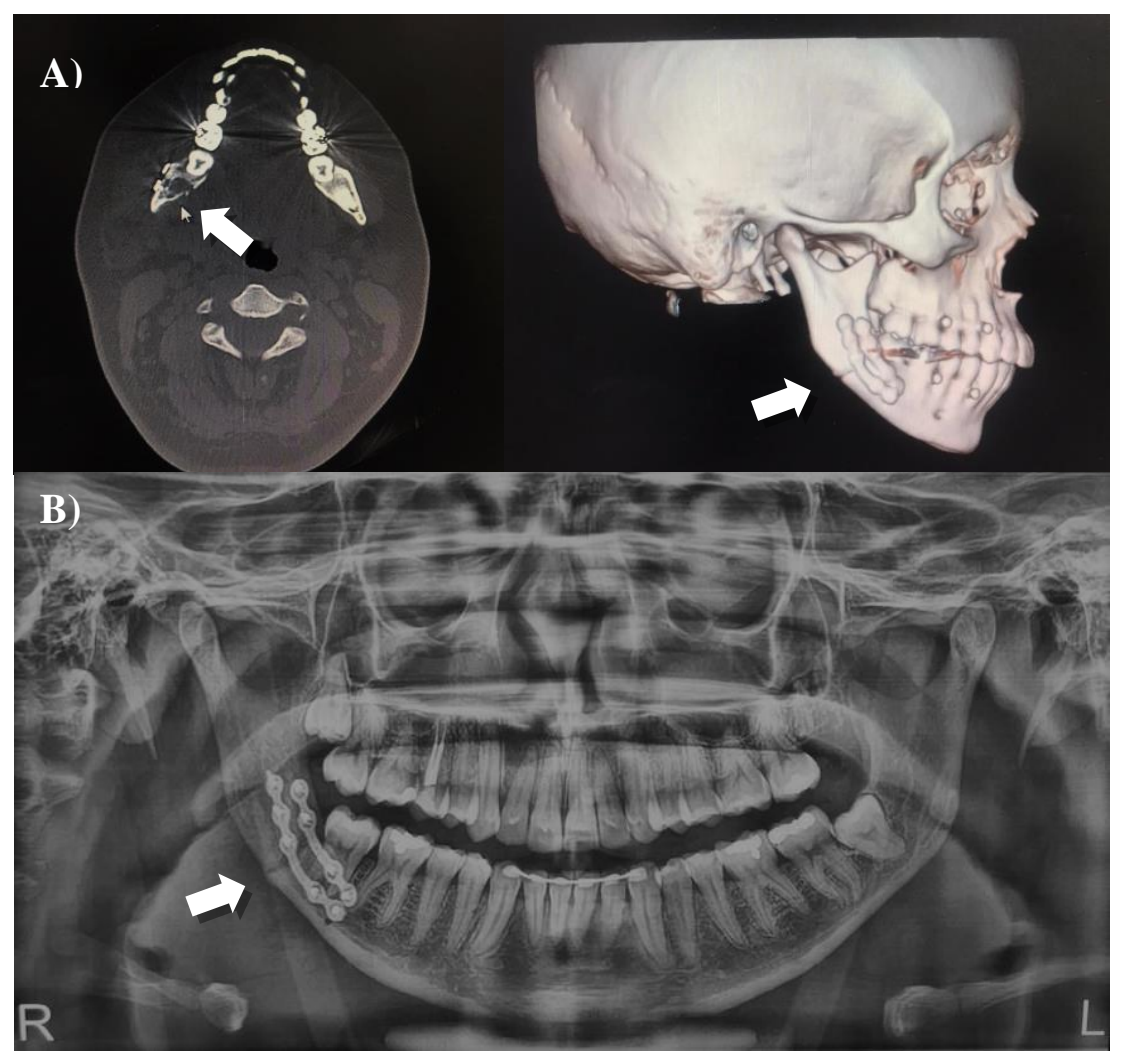

Source: Own authorship.

\section{Discussion}

The literature reports very well about the mandibular fractures associated with the third molar and the indication for their treatment (Özçakir-Tomruk \& Arslan, 2012; Perry \& Goldberg, 2000). In intraoperative extractions, besides the planning, the mandibular fracture can occur due to different factors as wide ostectomy, improper instrumentation, application of excessive force to the bone, and the experience of the surgeon (Özçakir-Tomruk \& Arslan, 2012; Cankaya et al. 2011). However, the late fracture is a possibility that can occur until the fourth week of postoperative (Capalbo et al. 2020; Pires et al. 2017; Grau-Manclús et al. 2011; Krimmel \& Reinert, 2000). This fracture is either related to perioperative due to factors such as wide ostectomy as the not respect of orientations, chewing hard foods (Özçakir-Tomruk \& Arslan, 2012; Grau-Manclús et al. 2011). In our case report patient did not hear any sound in postoperative, but immediately after the surgery presented complaints as moderate pain, malocclusion, and limited movement of the mandible, but related this with the surgery and maintained a soft food. These factors suggested that the fracture happened in the perioperative moment. Mandible fractured in the right side do not corroborate with some authors that report that a higher incidence of fractures on the left side reflects the dentist's position that applies an uncontrolled force by a right-handed surgeon (Pires et al. 2017; Cankaya et al. 2011). However, the fracture in this side relates to the ostectomy, and the force applied for the surgeon. These occur even been a 
right-handed surgeon and a right third molar. In the postoperative, the bite force can generate a considerable amount of stress in the bone region, which already has less volume due to the ostectomy and/or local alterations (Pires et al. 2017).

Injuries Mandibles are related to a dentistry practice and reported in the literature (He et al. 2011; Koskela et al. 2017). The dentist's attention is crucial for all treatments moments and in the postoperative to avoid malpractice. In literature, the third molar extractions are the chief causes of malpractice that results in injuries, ranging from lingual nerve injury to death, including the mandible fracture (He et al. 2011). The experience and the skills of the operator is imperative to reducing complications in extractions of the third molar this way can see that the general dentists were responsible for the majority, 78 $\%$ of complications, whereas oral and maxillofacial surgeons accounted for $15 \%$ (Ventä et al. 1998; Jerjes et al. 2010).

However, despite attention and planning, to avoid complications such as fractures, these can happen and need attention to the first complaints must be analyzed. Early diagnosis of fractures allows an improvement of the condition, as well as patient comfort. Therefore, in addition to clinical evaluation with manipulation of the mandible and occlusion assessment (Chrcanovic \& Custódio, 2010), the chief complaint about the patient's pain should not be neglected (Grau-Manclús et al. 2011). Because of these positives signs of the bone crackles, or bone steps, factors that facilitate the diagnosis, imaging exams allow closing the diagnosis (Chrcanovic \& Custódio, 2010; Grau-Manclús et al. 2011). The best and easiest accessibility exam for the patient is the panoramic radiography, which allows immediate assessment of the fracture, and determines the treatment depends on the displacement level. However, exams such as tomography assess displacements, loss of bone fragments, and displacement of dental elements and help to carry out a better planning (Chrcanovic \& Custódio, 2010; Pires et al. 2017).

Clinical and imaging diagnoses determine the treatment planning that will depend on fracture displacement. Nondisplacement or minor displacement fractures, the treatment option is closed reduction with IMF, allowing good results (Cankaya et al. 2011). This treatment can be performed by a general dental surgeon in an outpatient setting for these professionals.

However, in fractures like the case report in which the patient presents occlusion complains, and observe in imaging exams a fracture displacement the treatment with IMF not indicated. The best option is an open fracture treatment to allow better reduction, fixation of fractures, and stability of results. In addition, post-operative care should be advised as a soft diet for 45 days, as implemented in the case reported (Pires et al. 2017; Özçakir-Tomruk \& Arslan, 2012; Cankaya et al. 2011).

\section{Final Considerations}

Therefore, the points raised and presented with the case report we believe the important and the immediate care and investigation when patients present complaints after third molar removal. For this investigation, the clinical and imaging exam is important to apply the treatment as soon as possible.

\section{References}

Banks, P. (1991). Killey's Fractures of the Mandible. (4a ed.), Butterworth- Heinemann.

Cankaya, A. B., Erdem, M. A., Cakarer, S., Cifter, M., \& Oral, C. K. (2011). Iatrogenic mandibular fracture associated with third molar removal. International journal of medical sciences, 8(7), 547-553. https://doi.org/10.7150/ijms.8.547

Capalbo-Silva, R., Hadad, H., Piassi, J. E. V., Colombo, L. T., Mendes, B. C., Batista, F. R. de S., Garcia Júnior, I. R., \& Souza, F. Ávila de. (2020). Late mandibular fracture after attempted third molar surgery: case report. Archives of health investigation, 9(3). https://doi.org/10.21270/archi.v9i3.4673

Chrcanovic, B. R., \& Custódio, A. L. (2010). Considerations of mandibular angle fractures during and after surgery for removal of third molars: a review of the literature. Oral and maxillofacial surgery, 14(2), 71-80. https://doi.org/10.1007/s10006-009-0201-5

Grau-Manclús, V., Gargallo-Albiol, J., Almendros-Marqués, N., \& Gay-Escoda, C. (2011). Mandibular fractures related to the surgical extraction of impacted lower third molars: a report of 11 cases. Journal of oral and maxillofacial surgery: official journal of the American Association of Oral and Maxillofacial Surgeons, 69(5), 1286-1290. https://doi.org/10.1016/j.joms.2010.05.059 
He, P., Mah-Ginn, K., Karhade, D. S., Donoff, B., Adeeb, N., Gupta, R., Medford, S., \& Afshar, S. (2019). How Often Do Oral Maxillofacial Surgeons Lose Malpractice Cases and Why?. Journal of oral and maxillofacial surgery: official journal of the American Association of Oral and Maxillofacial Surgeons, 77(12), 2422-2430. https://doi.org/10.1016/j.joms.2019.07.001

Jerjes, W., Upile, T., Shah, P., Nhembe, F., Gudka, D., Kafas, P., McCarthy, E., Abbas, S., Patel, S., Hamdoon, Z., Abiola, J., Vourvachis, M., Kalkani, M., Al-Khawalde, M., Leeson, R., Banu, B., Rob, J., El-Maaytah, M., \& Hopper, C. (2010). Risk factors associated with injury to the inferior alveolar and lingual nerves following third molar surgery-revisited. Oral surgery, oral medicine, oral pathology, oral radiology, and endodontics, $109(3)$, 335-345. https://doi.org/10.1016/j.tripleo.2009.10.010

Koskela, S., Suomalainen, A., Apajalahti, S., \& Ventä, I. (2017). Malpractice claims related to tooth extractions. Clinical oral investigations, 21(2), 519-522. https://doi.org/10.1007/s00784-016-1896-y

Krimmel, M., \& Reinert, S. (2000). Mandibular fracture after third molar removal. Journal of oral and maxillofacial surgery: official journal of the American Association of Oral and Maxillofacial Surgeons, 58(10), 1110-1112. https://doi.org/10.1053/joms.2000.9566

Liu, Y. F., Wang, R., Baur, D. A., \& Jiang, X. F. (2018). A finite element analysis of the stress distribution to the mandible from impact forces with various orientations of third molars. Journal of Zhejiang University. Science. B, 19(1), 38-48. https://doi.org/10.1631/jzus.B1600552

Marciani R. D. (2007). Third molar removal: an overview of indications, imaging, evaluation, and assessment of risk. Oral and maxillofacial surgery clinics of North America, 19(1), 1-v. https://doi.org/10.1016/j.coms.2006.11.007

Miloro, M.; Ghali, G. E.; Larsen, P. E. \& Waite, P. D. (2008). Princípios de Cirurgia. Bucomaxilofacial de Peterson. 2 ed. São Paulo: Livraria Santos Editora.

Özçakir-Tomruk, C., \& Arslan, A. (2012). Mandibular angle fractures during third molar removal: a report of two cases. Australian dental journal, 57(2), 231-235. https://doi.org/10.1111/j.1834-7819.2012.01674.x

Peñarrocha-Diago, M., Camps-Font, O., Sánchez-Torres, A., Figueiredo, R., Sánchez-Garcés, M. A., \& Gay-Escoda, C. (2021). Indications of the extraction of symptomatic impacted third molars. A systematic review. Journal of clinical and experimental dentistry, 13(3), e278-e286. https://doi.org/10.4317/jced.56887

Perry, P. A., \& Goldberg, M. H. (2000). Late mandibular fracture after third molar surgery: a survey of Connecticut oral and maxillofacial surgeons. Journal of oral and maxillofacial surgery: official journal of the American Association of Oral and Maxillofacial Surgeons, 58(8), 858-861. https://doi.org/10.1053/joms.2000.8204

Pires, W. R., Bonardi, J. P., Faverani, L. P., Momesso, G. A., Muñoz, X. M., Silva, A. F., Panzarini, S. R., Bassi, A. P., \& Ponzoni, D. (2017). Late mandibular fracture occurring in the postoperative period after third molar removal: systematic review and analysis of 124 cases. International journal of oral and maxillofacial surgery, 46(1), 46-53. https://doi.org/10.1016/j.ijom.2016.09.003

Seeley-Hacker, B. L., Holmgren, E. P., Harper, C. W., Lauer, C. S., \& Van Citters, D. W. (2020). An Anatomic Predisposition to Mandibular Angle Fractures. Journal of oral and maxillofacial surgery: official journal of the American Association of Oral and Maxillofacial Surgeons, 78(12), 2279.e12279.e12. https://doi.org/10.1016/j.joms.2020.05.042

Soós, B., Janovics, K., Tóth, Á., Di Nardo, M. D., \& Szalma, J. (2020). Association Between Third Molar Impaction Status and Angle or Condylar Fractures of the Mandible: A Retrospective Analysis. Journal of oral and maxillofacial surgery: official journal of the American Association of Oral and Maxillofacial Surgeons, 78(7), 1162.e1-1162.e8. https://doi.org/10.1016/j.joms.2020.02.005

Ventä, I., Lindqvist, C., \& Ylipaavalniemi, P. (1998). Malpractice claims for permanent nerve injuries related to third molar removals. Acta odontologica Scandinavica, 56(4), 193-196. https://doi.org/10.1080/00016359850142772

Ventä I. (2012). How often do asymptomatic, disease-free third molars need to be removed? Journal of oral and maxillofacial surgery: official journal of the American Association of Oral and Maxillofacial Surgeons, 70(9 Suppl 1), S41-S47. https://doi.org/10.1016/j.joms.2012.04.037 